\title{
Normative and economic foundations of high- rise construction in the city of Samara
}

\author{
Olga V. Didkovskaya ${ }^{1}$ Aleksey $Y$. Bocharov ${ }^{1}$, Marina $V$. Ilyina ${ }^{1}$ and $O \lg a$ A. Mamaeva ${ }^{1}$ \\ ${ }^{1}$ Samara State Technical University, 443001 Molodogvardeyskaya St., Samara, Russia
}

\begin{abstract}
Every year the number of free land plots for construction of buildings is steadily decreasing in cities. In this regard, the participants in the investment and construction process are increasingly seeking to maximize the use of land. A logical way for this is to use high-rise construction. However, until recently, builders encountered serious obstacles in the form of lack of special norms and rules for the design of high-rise buildings. It led to the need for individual coordination of each high-rise facility, the development and approval of special technical conditions, the passage of numerous administrative approvals. Thus, investment activity regarding the construction of high-rise buildings in the Russian Federation is reduced. In 2016, there were regulatory changes that substantially alleviated these difficulties. In this article, the authors analyze the features of the town-planning normative-legal field of high-rise construction and its development, track the interrelations between the regulatory regulation of the construction of similar facilities, with the real need, the technical feasibility and economic feasibility of their construction in the urban district of Samara. Conclusions and suggestions are also based on the analysis of the norms of urban zoning, the residential real estate market and the value of land plots.
\end{abstract}

\section{Introduction}

The regulatory vacuum in the system of town-planning regulation in the Russian Federation with respect to the dynamically developing segment - construction of high-rise buildings - is finally overcome by the adoption in 2016 of codes of practice (SP): JV 253.1325800.2016 "Engineering systems of high-rise buildings" (introduced from 04.02.2017), SP 267.1325800.2016 "High-rise buildings and complexes" (introduced from 01.07.2017) [Ошибка! Источник ссылки не найден.,Ошибка! Источник ссылки не найден.]. With the introduction of these standards, all participants in the investment and construction process [Ошибка! Источник ссылки не найден.,Ошибка! Источник ссылки не найден.] will have the opportunity to act uniformly throughout the country in the construction of skyscrapers. Consequently, we can conclude that the Ministry of Construction of Russia is going to streamline the construction of high-rise buildings.

In this article, analytical, statistical and expert methods solve the problems of identifying the category of "high-rise buildings", studying the features of their design and

${ }^{1}$ Corresponding author: kafedra cen@mail.ru 
construction, establishing dependencies between the technical and economic indicators of high-rise construction.

\section{Methods}

Despite the approved JV, regulating the rules for the design of high-rise buildings and their engineering systems, the main question to which the unequivocal answer has not been received is "what is the height of the building that will be referred to the category of highrise buildings?".

For this purpose, the current system of regulatory legal regulation of the issue was monitored and analyzed. It was found out that the height of buildings in various normative documents is determined in different ways depending on the tasks for which the content of the norm or the law is directed:

- SP 42.13330.2011 "Urban planning. Planning and development of urban and rural settlements"- meters (the maximum parameter -" objects height from the surface of the earth $50 \mathrm{~m}$ and more ") [Ошибка! Источник ссылки не найден.];

- SP 54.13330.2011 "Residential apartment buildings" - meters (the maximum parameter

- "this code of rules applies to the design and construction of newly constructed and reconstructed multi-apartment residential buildings up to $75 \mathrm{~m}$ high") [Ошибка! Источник ссылки не найден.];

- SP 14.13330.2014 "Construction in seismic regions" - meters (the maximum parameter - "designing of buildings with a height of more than $75 \mathrm{~m}$ should be carried out with the support of a competent organization") [Ошибка! Источник ссылки не найден.];

- JV 118.13330.2012 "Public buildings and structures" - meters (maximum parameter "this code of rules applies to the design of new, reconstructed and overhauled public buildings and structures up to $55 \mathrm{~m}$ high") [Ошибка! Источник ссылки не найден.];

- SP 253.1325800.2016 "Engineering systems of high-rise buildings" - meters (maximum parameter - "this set of rules applies to the design of engineering systems of newly constructed and reconstructed public buildings of more than $55 \mathrm{~m}$ in height and residential buildings of more than $75 \mathrm{~m}$ in height, including multifunctional buildings and buildings of one Functional purpose ") [Ошибка! Источник ссылки не найден.];

- SP 267.1325800.2016 "High-rise buildings and complexes. Design rules »- meters (the maximum parameter -" this code of rules can be used in the design and construction of public buildings above $50 \mathrm{~m}$, as well as multifunctional buildings in which public spaces are located at an altitude of more than $50 \mathrm{~m}$ ") [Ошибка! Источник ссылки не найден.];

- SP 160.1325800.2014 "Buildings and complexes multifunctional. Design rules »meters (maximum parameter -" this code of rules applies to the design and construction of new, reconstructed and overhauled multifunctional buildings up to $75 \mathrm{~m}$ high with the placement of public premises on floors not higher than $55 \mathrm{~m}$ ") [Ошибка! Источник ссылки не найден.];

- Federal Law No. 123-FZ "Technical Regulations on fire safety requirements" - floors and meters (the maximum parameter is "more than 17 floors or 50 meters" [Ошибка! Источник ссылки не найден.]);

- Urban Development Code of the Russian Federation - meters (the maximum parameter unique elevations include "a height of more than 100 meters") [Ошибка! Источник ссылки не найден.].

Thus, from the above analysis of existing regulations, which refer to the height or number of storeys, we can conclude that the notion of a high-rise building is ambiguous. 
Even in newly adopted joint ventures, the difference in determining the altitude is $25 \mathrm{~m}-50$ $\mathrm{m}$ and $75 \mathrm{~m}$.

Graphical interpretation of the variability of the regulatory requirements for altitude is shown in Fig. 1.

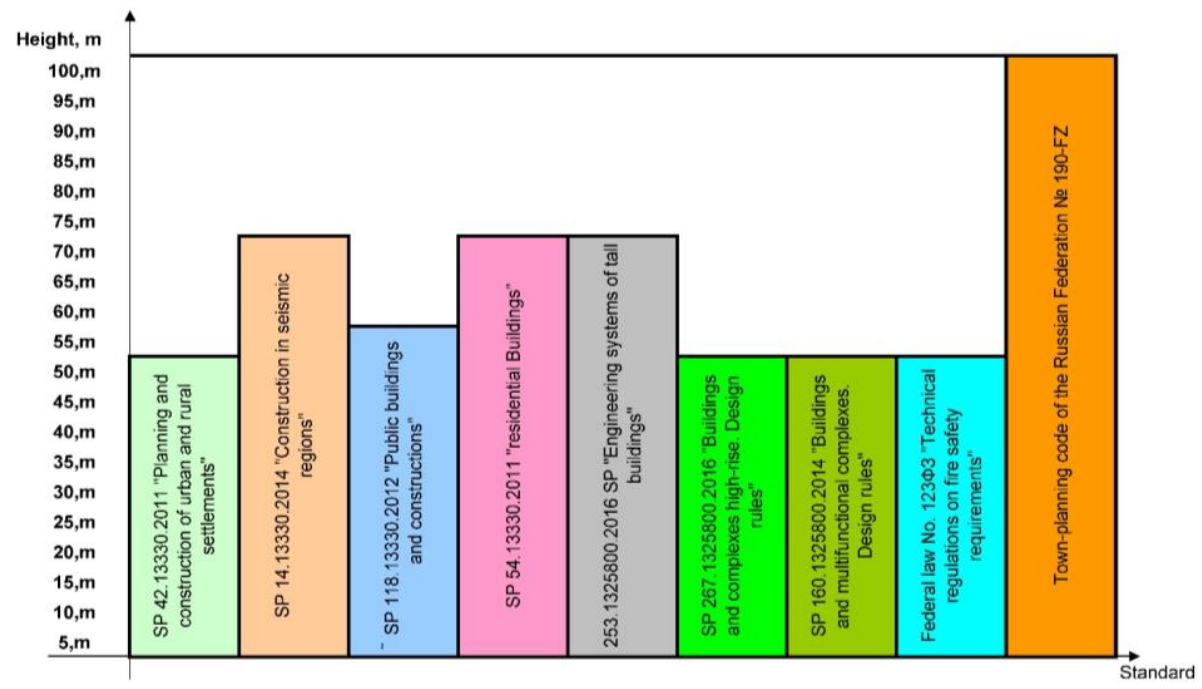

Fig. 1. Regulations for high-rise construction

Based on the results of the analysis of the new joint venture, a number of the following most important provisions can be distinguished when designing high-rise buildings:

- The JV contains stringent requirements agreed with the experts of the Ministry for Emergency Situations of the Russian Federation regarding the safety of construction for buildings with a height of more than 50 meters;

- the need to use structures with an increased fire resistance limit is fixed;

- Provide backup power supply;

- the need is fixed for all floors of equipment of isolated security zones for inactive citizens, where they could wait for firefighters;

- provides for the presence of a refractory service elevator for rescuers, and also takes into account the requirements and regulations for the smoke removal system.

The above requirements significantly increase the unit cost of construction in high-rise buildings (cost per square meter of the total area). At the same time, additional costs arising in comparison with other capital construction objects are made to ensure the safety of users, therefore owners (tenants, users) will demand for such areas.

The interconnected urban planning requirements for the height of buildings the size of the land plots on which they are located are contained in Chapter 4 "Urban Planning Zoning" of the Urban Development Code of the Russian Federation. In particular Art. 38 defines "the maximum (minimum and (or) maximum) sizes of land plots and the maximum parameters of permitted construction, reconstruction of capital construction objects", namely "the maximum number of floors or the maximum height of buildings, structures, structures." Sub-legal requirements are defined in the "Rules of land use and development in the city of Samara" - a document of town-planning zoning, which is approved by the regulatory legal acts of local governments, regulatory legal acts of the state authorities of the constituent entities of the Russian Federation and establishes territorial zones, town planning regulations [Ошибка! Источник ссылки не найден.]. 
On the basis of this standard, Table 1 is compiled reflecting the parameters of the maximum permissible number of storeys (altitude) of residential and non-residential buildings in the city of Samara.

Table 1. The maximum allowable number of storeys (high-rise) residential and non-residential buildings in the g. o. Samara

\begin{tabular}{|c|c|c|}
\hline \multirow[b]{2}{*}{ Types of territorial zones } & \multicolumn{2}{|c|}{ Maximum height of buildings } \\
\hline & $\begin{array}{l}\text { The main permitted uses } \\
\text { of land }\end{array}$ & $\begin{array}{c}\text { Ypes of real } \\
\text { estate use that } \\
\text { require special } \\
\text { approval } \\
\end{array}$ \\
\hline \multicolumn{3}{|c|}{ Zones of business and service functions } \\
\hline $\begin{array}{l}\text { C-1 Zone of business and commercial enterprises within } \\
\text { the boundaries of the historical part of the central district }\end{array}$ & $\begin{array}{l}\text { Multi-apartment houses } \\
\text { (MCD) up to } 3 \text { floors }\end{array}$ & $\begin{array}{l}\text { MCD above } 3 \\
\text { floors }\end{array}$ \\
\hline C-2 Zone of regional and city centers & MCD over 4 floors & MCD up to 5 floors \\
\hline C-3 Service area of local (district) population & MCD above 3 floors & $\begin{array}{l}\text { Residential } \\
\text { buildings (railway) } \\
\text { up to } 3 \text { floors }\end{array}$ \\
\hline $\begin{array}{c}\text { C-4c Zone of specialized commercial use of sports and } \\
\text { entertainment facilities }\end{array}$ & - & - \\
\hline $\begin{array}{l}\text { С-4т Zone of specialized commercial use of public } \\
\text { transport facilities }\end{array}$ & - & - \\
\hline $\begin{array}{l}\text { C-5m Zone of specialized non-commercial use of medical } \\
\text { facilities }\end{array}$ & - & - \\
\hline $\begin{array}{l}\text { C-5H Zone of specialized non-commercial use of } \\
\text { educational and scientific facilities }\end{array}$ & - & - \\
\hline $\begin{array}{c}\text { C-5к Zone of specialized non-commercial use of objects } \\
\text { related to the worship }\end{array}$ & - & - \\
\hline \multicolumn{3}{|c|}{ Residential areas } \\
\hline G-1 Zone of low-rise buildings with individual houses & $\begin{array}{l}\text { Railway station up to } 3 \\
\text { floors / } 12 \mathrm{~m}\end{array}$ & $\begin{array}{l}\text { Railway station up } \\
\text { to } 4 \text { floors / } 12 \mathrm{~m}\end{array}$ \\
\hline G-2 Low-rise mixed residential development zone & $\begin{array}{l}\text { Railway station up to } 4 \\
\text { floors } / 12 \mathrm{~m}, \mathrm{MKD} / 15 \mathrm{~m}\end{array}$ & - \\
\hline G-3 Medium-rise residential area of 3-6 floors & MKD up to 6 floors / $30 \mathrm{~m}$ & $\begin{array}{l}\text { MKD above } 6 \\
\text { floors / } 51 \mathrm{~m}\end{array}$ \\
\hline $\begin{array}{l}\text { G-4 Zone of multi-storey residential development of 5-16 } \\
\text { floors }\end{array}$ & $\begin{array}{l}\text { MKD up to } 9 \text { floors in the } \\
\text { historical part of the city / } 30 \\
\text { m or MKD above } 5 \text { floors } \\
\text { outside the historical part of } \\
\text { the city / } 51 \mathrm{~m}\end{array}$ & $\begin{array}{l}\text { MKD above } 9 \\
\text { floors in the } \\
\text { historical part of } \\
\text { the city / } 51 \mathrm{~m}\end{array}$ \\
\hline G-5 Zone of planned housing & - & - \\
\hline \multicolumn{3}{|c|}{ Recreation Area } \\
\hline $\mathrm{P}-1$ Zone of the center of recreational areas & - & - \\
\hline P-2 Zone of parks, boulevards, embankments & - & - \\
\hline P-3 Zone of natural landscapes & - & - \\
\hline P-4 Zones of Specially Protected Natural Areas & - & - \\
\hline P-5 Area of horticultural sites and collective gardens & - & - \\
\hline \multicolumn{3}{|c|}{ Industrial and communal areas } \\
\hline $\begin{array}{l}\text { PC-1 Zone of enterprises and warehouses of V-IV hazard } \\
\text { classes (sanitary protection zones - up to } 100 \mathrm{~m} \text { ) }\end{array}$ & - & - \\
\hline $\begin{array}{l}\text { PK-2 Zone of enterprises and warehouses of the third } \\
\text { class of harmfulness (sanitary protection zones - up to } \\
\qquad 300 \mathrm{~m} \text { ) }\end{array}$ & - & - \\
\hline $\begin{array}{l}\text { PC-3 Zone of enterprises and warehouses of II-I hazard } \\
\text { classes (sanitary protection zones - up to } 500 \mathrm{~m} \text { and } \\
\text { more) }\end{array}$ & - & - \\
\hline Rzv Reserve areas & - & - \\
\hline
\end{tabular}

Based on the analysis of Table. 1, we can conclude that the data on the maximum parameter of buildings are limited to 51 meters. Therefore, given that this type of document 
regulates the parameter of permitted building of ordinary buildings, we can assume that the height of $51 \mathrm{~m}$ is the minimum height with which high-rise buildings begin. In this case, buildings taller than 100 meters in accordance with the Town Planning Code of the Russian Federation are unique.

\section{Results}

Analysis of the regulatory legal framework of the issue under consideration allows us to define the category of "high-rise buildings" for the conditions of their construction in the territory of the city. Samara with the following parameters:

- height - more than 50 meters;

- storeys - more than 17 floors;

- accommodation in the residential development zone Zh-3, Zh-4;

- possible placement in the area of business and service functions.

The assumption of the prospects for the development of high-rise construction in the city of Samara was made by the authors on the basis of the analysis of the map "Rules of building and land use in the city of Samara"[11].

From the analysis of the map of the "Rules of development and land use in the city of Samara" we can conclude that the potential location of skyscrapers is possible in an area of up to $10 \%$ of the city. This is a high index in comparison with the majority of cities in both the Volga Federal District [Ошибка! Источник ссылки не найден.] and the Russian Federation as a whole.

Next, we will analyze the housing market in the city. Samara for March - April 2017 in the context of proposals for the sale of apartments in buildings with a distribution by altitude. According to the number of storeys, the apartment houses are conditionally divided into five groups [Ошибка! Источник ссылки не найден.]:

- low-rise - with a height of 1-3 floors (up to 9 meters);

- medium storeys - 4-5 floors (up to 15 meters);

- increased number of storeys - 6-9 floors (up to 27 meters);

- multi-storey - 10-16 floors (up to 48 meters);

- high-rise - more than 17 floors (more than 51 meters).

This division formed the basis for the analysis of the market of apartments in multiapartment houses (hereinafter referred to as MCD) (see Table 2).

Table 2. Distribution of the offer of the market of apartments in inhabited multi-apartment houses by number of storeys

\begin{tabular}{|c|c|c|c|}
\hline $\begin{array}{l}\text { No. in } \\
\text { order }\end{array}$ & MKD group of storeys & $\begin{array}{c}\text { Number of } \\
\text { apartments, } \\
\text { pcs. }\end{array}$ & Share of total, \% \\
\hline 1 & Low-rise & 133 & 9,72 \\
\hline 2 & Average number of storeys & 477 & 34,87 \\
\hline 3 & Elevated number of storeys & 314 & 22,95 \\
\hline 4 & Multi-storey & 336 & 24,56 \\
\hline 5 & $\begin{array}{l}\text { High-altitude - more than } 17 \text { floors (more than } 51 \\
\text { meters) }\end{array}$ & 108 & 7,89 \\
\hline & Total & 1368 & $\mathbf{1 0 0 , 0 0}$ \\
\hline
\end{tabular}

Analysis of Table. 2, shows that the segment "high-rise buildings" in the residential real estate market. Samara is represented by 108 offers for sale, which is almost $8 \%$ of the total market of apartments. In Table. 3 presents the price analysis of the market for the supply of apartments in the MKD in the context of their accepted classification by number of storeys. 
Table. 3 shows that the dependence of the cost of an apartment on the height of the building on the market is present, although it is substantially smoothed as the number of storeys increases. Further, the market of apartments located in high-rise buildings was investigated (Table 4).

Table 3. Analysis of the average cost of apartments in residential apartment buildings, depending on the number of storeys

\begin{tabular}{|c|c|c|}
\hline $\begin{array}{c}\text { No. } \\
\text { in } \\
\text { order }\end{array}$ & The group of number of storeys & $\begin{array}{c}\text { The average cost of 1 square meter, } \\
\text { thousand rubles. }\end{array}$ \\
\hline 1 & Low-rise & 47,07 \\
\hline 2 & Average number of storeys & 59,50 \\
\hline 3 & Elevated number of storeys & 65,33 \\
\hline 4 & Multi-storey & 66,52 \\
\hline 5 & $\begin{array}{c}\text { High-altitude - more than 17 floors (more than } \\
\text { 51 meters) }\end{array}$ & 68,46 \\
\hline
\end{tabular}

Table 4. Distribution of apartments in high-altitude MKD by districts of the city. Samara

\begin{tabular}{|c|c|c|c|}
\hline $\begin{array}{c}\text { No. in } \\
\text { order }\end{array}$ & Districts of the city & Number of apartments, pes. & Share of total,\% \\
\hline 1 & Railway district & 23 & 21,30 \\
\hline 2 & Kirovsky district & 5 & 4,63 \\
\hline 3 & Leninsky district & 11 & 10,19 \\
\hline 4 & Oktyabrsky district & 50 & 46,30 \\
\hline 5 & Industrial area & 16 & 14,81 \\
\hline 6 & Samara Region & 1 & 0,93 \\
\hline 7 & Sovetskiy district & 2 & 1,85 \\
\hline & Total: & $\mathbf{1 0 8}$ & $\mathbf{1 0 0 , 0 0}$ \\
\hline
\end{tabular}

Analysis of Table 4 showed that more than $92 \%$ of all "high-rise" apartments are located in four of the seven districts of the city. Kuybyshevsky and Krasnoglinsky districts do not have objects related to the "high-rise buildings" segment on their territory, therefore they are not presented in Table 4.

\section{Discussion}

For the discussion in this article, the following research results and suggestions of the authors are made:

- the assumption of the development of high-rise construction in the territory of the city of. Samara, made on the basis of an analysis of the rules of land use and development (Table 1, Figure 2);

- dependence of the cost of the apartment on the building's height, established as a result of the analysis of the residential property supply market (Table 3, Figure 3);

- dependence of the supply of apartments in high-altitude MKD on the value of the ratio of the value of 1 sq.m. Of the land to the cost of 1 sq.m. Apartments (Table 5, Figure 4).

The figure presented below. 3 reflects the form of the statistical dependence of the average cost of flats (1 sq.m.) on the number of floors in which they are located, detected analytically (Table 3). The logarithmic function in this case is the most reliable (reliability of approximation $(\mathrm{R} 2=0.959)$ ) for constructing the trend. This contributed to several factors: first, the area of the apartment, and secondly the quality of the finish. These factors were not taken into account in this study. 


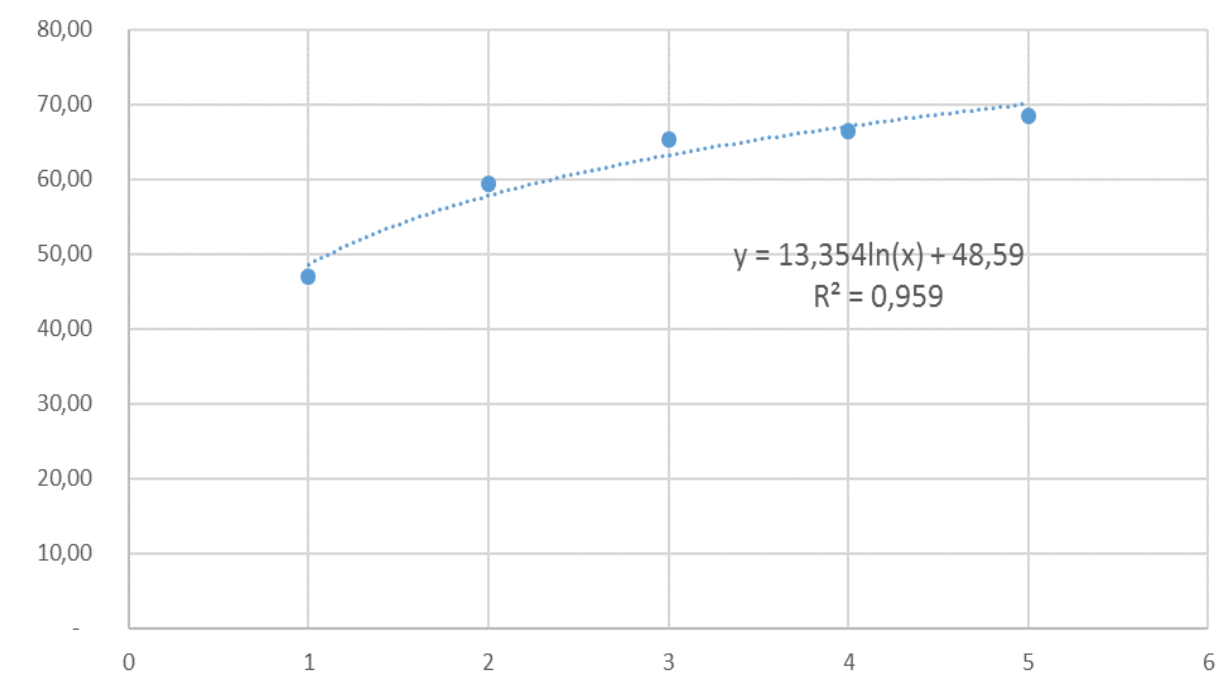

Fig. 3. The logarithmic dependence of the average cost of apartments (1 sq.m.) on the number of storeys

Table. 5 and Fig. 4 illustrate the relationship between the cost of land and apartments in high-altitude MKD.

Table 5. Analysis of the average cost of apartments in high-altitude MKD and the value of land plots by districts of the city. Samara

\begin{tabular}{|c|c|c|c|c|}
\hline $\begin{array}{c}\text { No. in } \\
\text { order }\end{array}$ & Districts of the city & $\begin{array}{c}\text { The average } \\
\text { cost of 1 square } \\
\text { meter, } \\
\text { thousand } \\
\text { rubles. }\end{array}$ & $\begin{array}{c}\text { The average cost of 1 } \\
\text { sq.m. of the land } \\
\text { plot, thousand rub. }\end{array}$ & $\begin{array}{c}\text { The cost ratio of 1 } \\
\text { sq.m. of the land to } \\
\text { the cost of 1 sq.m. } \\
\text { apartments, \% }\end{array}$ \\
\hline 1 & Leninsky district & 86,06 & 11,90 & $14 \%$ \\
\hline 2 & Oktyabrsky district & 64,75 & 6,38 & $10 \%$ \\
\hline 3 & Railway district & 67,80 & 5,98 & $9 \%$ \\
\hline 4 & Industrial area & 67,11 & 5,90 & $9 \%$ \\
\hline 5 & Sovetskiy district & 73,02 & 4,17 & $6 \%$ \\
\hline 6 & Kirovsky district & 72,39 & 3,30 & $5 \%$ \\
\hline 7 & Samara Region & 130,47 & 7,00 & $5 \%$ \\
\hline
\end{tabular}

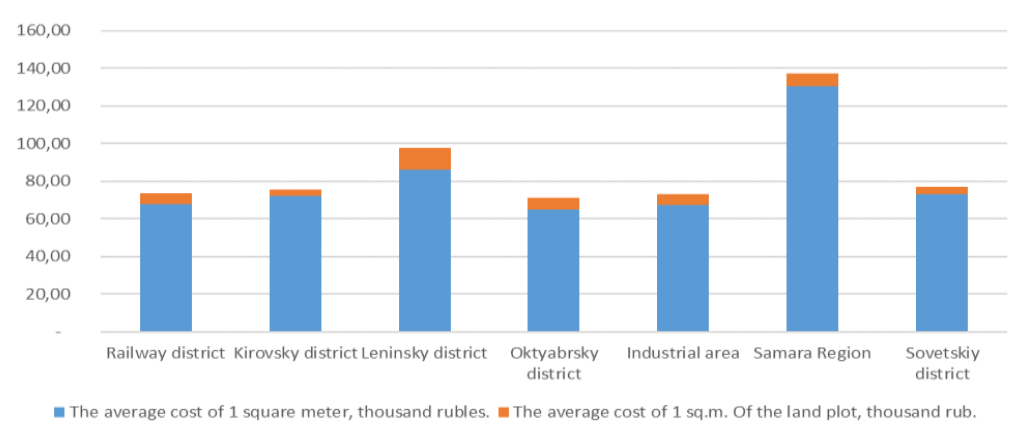

Fig. 4. Share of the cost of 1 sq.m. of the land plot to the cost of 1 sq.m. apartments 
From the analysis of Table 5, it can be assumed that there is a dependence of the supply volume in the segment of the sale of apartments in high-rise apartment blocks of multiapartment buildings on the ratio of the average value of land plots and apartments. Those. From Table 5, it can be seen that when the indicator "Value ratio of 1 sq.m. Of the land to the cost of 1 sq.m. Apartments "the share of the land plot in the cost of apartments in highrise apartment buildings is reduced (Figure 4).

This conclusion is made on the basis of a short-term study of the local market and requires detailed comprehensive study. Lonely this circumstance is quite logical, i.e. With growing demand for the final construction product - flat (in the case under consideration), calculation of demand for land in a certain location (area) [14 - Ошибка! Источник ссылки не найден.]. And this circumstance in turn prompts the builder to increase the number of storeys, thereby reducing the share of the land plot in the cost of the apartment.

\section{Conclusion}

The construction of high-rise buildings, the number of floors of which has already reached a hundred, is a promising area in urban development. The ability to locate on a relatively small plot of land a huge amount of residential and commercial space makes the construction of skyscrapers very attractive for developers. In the Russian Federation in general and in the Samara region in particular, high-rise construction was accompanied and accompanied by many difficulties. In this connection, this type of construction does not have a high investment attractiveness.

Strengthening the legitimacy of design and construction standards in this area, in the opinion of the authors, will contribute to the orientation of the construction complex of the region for capital investments in the construction of high-rise buildings of various functional purposes [0-Ошибка! Источник ссылки не найден.].

The comprehensive analysis of town-planning norms, land and real estate markets and the dependencies established on their basis show the developers economic and other prospects for building high-rise buildings in the capital of the region

\section{References}

1. http://docs.cntd.ru/document/456044284 (date of circulation: 04.24.2017).

2. http://docs.cntd.ru/document/1200139948.

3. http://docs.cntd.ru/document/1200084712 (reference date: April 24, 2017).

4. http://docs.cntd.ru/document/1200084096 (reference date: April 24, 2017).

5. http://docs.cntd.ru/document/1200111003 (the date of the application: 04.24.2017).

6. http://docs.cntd.ru/document/1200092705 (reference date: April 24, 2017).

7. http://docs.cntd.ru/document/1200113272 (reference date: April 24, 2017).

8. http://docs.cntd.ru/document/902111644 (date of circulation: 04.24.2017).

9. http://docs.cntd.ru/document/901919338 (reference date: April 24, 2017).

10. http://docs.cntd.ru/document/945005955 (reference date: April 24, 2017).

11. http://map.samadm.ru/pzz/ (date of circulation: 04.24.2017).

12. http://pfo.gov.ru (reference date: 04.24.2017).

13. I. A. Sinyansky, Typology of buildings: a textbook for stud. Establishments of environments. Prof. Education I. A. Sinyansky, N. I. Maneshina, 288 (Moscow, Publishing Center "Academy", 2014) ISBN 978-5-4468-0595-2 
14. M. I. Balzannikov, A. A. Mikhasek, V. P. Popov, Study Results Assessment of Quickhardening Liquids Penetration into Soil Elements of Hydraulic Engineering Constructions, Procedia Engineering

15. E. E. Kireeva, A. D. Kornilova, Research of Instruments for Financing of Innovation and Investment Construction Projects, Procedia Engineering

16. O. Mamaeva, A. Bocharov, Construction audit as a modern instrument of investment and construction process management, MATEC Web of Conferences 86, 05007

17. O. V. Didkovskaya, O. G. Mamayeva, Development of Cost Engineering System in Construction, Procedia Engineering

18. S. V. Domnina, E. V. Savoskina, N. V. Shekhova, On Innovative Decisions in the Investment-construction Cycle, Procedia Engineering.

19. E. M. Generalova, V. P. Generalov, A. A. Kuznetsova, Modular Buildings in Modern Construction, Procedia Engineering.

20. Y. V. Sidorenko, S. F. Korenkova, Self-organization processes in silicate and cement construction materials, Solid State Phenomena.

21. T. Y. Vavilova, N. D. Potienko, I. V. Zhdanova, On Modernization of Capital Construction Projects in the Context of Sustainable Development of Social Sphere, Procedia Engineering.

22. D. V. Zelentsov, K. L. Chertes, O. V. Tupicina, Theoretical Basis and Experimental Study of the Aeration Characteristics of the Composting Mixtures during the Design and Construction of the Aeration System of the Oily Waste Biodegradation Complex, Procedia Engineering, 153, 903-908

23. A. Bocharov, I. G. Burtsev, Cost Engineering Investment-construction project Economic aspects of management of the building complex in modern conditions: a collection of articles ed. M.I. Balzannikova, K.S. Galitskova, N.V. Shekhovoy; SGAU, 224-229 (Samara, 2016)

24. Yu. P. Sologubov, T. E. Gordeeva, Analysis of planning solutions for residential buildings for energy efficiency, Urban planning and architecture, 4(21), 104-107 (2015) 